\title{
Ichthyofilaria argentinensis sp. nov. (NEMATODA: PHILOMETRIDAE) PARÁSITA DE Merluccius hubbsi (PISCES: MERLUCCIIDAE) \\ Ichthyofilaria argentinensis sp. nov. (NEMATODA: PHILOMETRIDAE) PARASITE OF Merluccius hubbsi (PISCES: MERLUCCIIDAE)
}

\author{
Inés Silvia Incorvaia \\ Instituto Nacional de Investigación y Desarrollo Pesquero (INIDEP) \\ Paseo Victoria Ocampo No. 1 \\ 7600 Mar del Plata, Buenos Aires, Argentina \\ E-mail: incor@inidep.edu.ar
}

Recibido en agosto de 1998; aceptado en mayo de 1999

\section{RESUMEN}

En el presente trabajo se describe una nueva especie de nematodo, Ichthyofilaria argentinensis, que parasita la vejiga natatoria de la merluza común, Merluccius hubbsi Marini, 1933, del sector del Atlántico Sudoccidental comprendido entre $34^{\circ}$ y $48^{\circ} \mathrm{S}$. Ichthyofilaria argentinensis sp. nov. se caracteriza por tener cutícula lisa y cuerpo fusiforme. La boca es simple, no presenta labios. El esófago, robusto, está dividido en dos porciones, una anterior muscular y una posterior glandular, de la cual se origina un apéndice glandular libre, dirigido posteriormente.

Palabras clave: nematodos, Philometridae, Ichthyofilaria argentinensis, merluza.

\begin{abstract}
The present work deals with a new nematode species, Ichthyofilaria argentinensis, found in the swim bladder of the Argentine common hake, Merluccius hubbsi Marini, 1933, from the Southwest Atlantic sector between $34^{\circ}$ and $48^{\circ} \mathrm{S}$. Ichthyofilaria argentinensis sp. nov. is characterized by its smooth cuticle and fusiform body. The mouth is simple and does not have lips. The robust oesophagus is divided into two sections, an anterior muscular and a posterior glandular, from which a free glandular appendage arises, directed backwards.
\end{abstract}

Key words: nematodes, Philometridae, Ichthyofilaria argentinensis, hake.

\section{INTRODUCCIÓN}

El estudio de los helmintos parásitos de Merluccius hubbsi fue abordado primeramente por Szidat (1955) con el objeto de inferir el posible origen de la merluza del Atlántico Sudoccidental. Posteriormente se estudiaron los digeneos y los monogeneos.

\section{INTRODUCTION}

The study of helminth parasites of Merluccius hubbsi was first tackled by Szidat (1955) in order to determine the possible origen of the Argentine hake from the Southwest Atlantic. The Digenea and Monogenea were subsequently studied. 
El presente trabajo se refiere a una nueva especie de nematodo, Ichthyofilaria argentinensis, cuyas características anatómicas permitieron ubicarla taxonómicamente en la familia Philometridae, subfamilia Philometrinae y el género Ichthyofilaria Yamaguti, 1935.

\section{MATERIALES Y MÉTODOS}

Se examinaron 351 ejemplares de $M$. hubbsi provenientes de la plataforma del Mar Argentino $\left(34^{\circ}\right.$ a $\left.48^{\circ} \mathrm{S}\right)$. Los parásitos se recolectaron de la vejiga natatoria con ayuda de una aguja y pinza de disección, fijados en AFA (solución de ácido acético-formol-alcohol) y diafanizados en alcohol glicerinado.

Las observaciones se realizaron con un microscopio Leitz Dialux 20 EB y los dibujos con la cámara clara incorporada al mismo. Las medidas están dadas en milímetros de la siguiente manera: la media y entre paréntesis el rango.

\section{RESULTADOS}

De la vejiga natatoria de $M$. hubbsi se recolectó una especie de nematodo cuyas características anatómicas permitieron ubicarla taxonómicamente en la familia Philometridae, subfamilia Philometrinae y el género Ichthyofilaria Yamaguti, 1935. En el seno de este género es una especie nueva, para la cual se propone el nombre de Ichthyofilaria argentinensis.

\section{Ichthyofilaria argentinensis sp. nov.} Descripción general

Hembra: El cuerpo es blanco, fusiforme, de cutícula muy delgada y lisa. Su extremidad anterior es simple, careciendo de proyecciones cefálicas. La boca simple no presenta labios. El esófago, robusto, está dividido en dos porciones, la anterior, muscular y alargada, con dos expansiones separadas por el anillo nervioso, y la posterior, glandular, de la cual se origina un apéndice glandular libre, dirigido posteriormente.
This work deals with a new nematode species, Ichthyofilaria argentinensis, whose anatomical characteristics have allowed it to be classified as belonging to the family Philometridae, subfamily Philometrinae and genus Ichthyofilaria Yamaguti, 1935.

\section{MATERIALS AND METHODS}

An examination was made of 351 specimens of $M$. hubbsi from the shelf of the Argentine Sea $\left(34^{\circ}\right.$ to $\left.48^{\circ} \mathrm{S}\right)$. The parasites were collected from the swim bladder using a dissecting needle and tweezers, fixed in AFA (solution of acetic acidformol-alcohol) and cleared in glycerine alcohol.

The observations were made with a Leitz Dialux 20 EB microscope and the drawings with a light chamber mounted on the microscope. The measurements are given in millimeters, as follows: the mean followed by the range in parentheses.

\section{RESULTS}

A nematode species was collected from the swim bladder of $M$. hubbsi. Based on its anatomical characteristics, it has been taxonomically included in the family Philometridae, subfamily Philometrinae and genus Ichthyofilaria Yamaguti, 1935. It is a new species of this genus and the name proposed for it is Ichthyofilaria argentinensis.

Ichthyofilaria argentinensis sp. nov. General description

Female: White, fusiform body, with very thin and smooth cuticle. Simple anterior end, lacking cephalic projections. The mouth is simple and does not have lips. The robust oesophagus is divided into two sections, the anterior, muscular and elongated, with two swellings that are separated from each other by the nerve ring, and the posterior, glandular, from which a free glandular appendage arises, directed backwards. 
Macho: Desconocido.

El cuerpo mide 25.07 (18.64-34.32) de largo y 0.57 (0.38-0.84) de ancho, la relación largo/ancho del cuerpo es de 44:1.

El esófago mide $0.49(0.38-0.60)$ de largo, su porción muscular anterior (Em) es de 0.45 (0.38-0.54); la relación entre el largo del cuerpo y ésta es de 58:1. La porción glandular posterior (Eg) es de $0.06(0.05-0.08)$, de la cual se origina un apéndice glandular (Ap), libre de 0.15 $(0.14-0.18)$ de largo.

El anillo nervioso (An) se encuentra a 0.31 (0.21-0.48) de la extremidad anterior (fig. 1). El aparato genital es didélfico; el ovario anterior está reducido y el ovario posterior (Ov) dista 0.74 de la extremidad posterior del cuerpo, carece de vulva. El intestino (In) corre ventralmente al ovario; la cola mide $0.64(0.56-0.70)$ de largo (fig. 2).

Las larvas, filiformes, halladas en el interior del útero (Ut) de los adultos, miden 0.11 (0.074-0.15). El estudio bajo microscopio óptico no permitió diferenciar la anatomía interna de las mismas (fig. 3).

Material estudiado: 150 ejemplares. Las medidas que se indican corresponden a 25 hembras.

Localización en el hospedador: Vejiga natatoria.

Hospedador: Merluccius hubbsi Marini, 1933.

Localidad: Océano Atlántico Sudoccidental (34 a $48^{\circ} \mathrm{S}$ ).

Material tipo: Depositado en la colección del Instituto Nacional de Investigación y Desarrollo Pesquero, holotipo No. $0054 \mathrm{H}$; paratipo No. $0065 \mathrm{H}$.

\section{Male: Unknown.}

The body is 25.07 (18.64-34.32) long and 0.57 $(0.38-0.84)$ wide; the body length/width ratio is 44:1.

The oesophagus measures $0.49(0.38-0.60)$ in length, the anterior muscular portion $(\mathrm{Em})$ is 0.45 (0.38-0.54); the ratio between body length and the latter is 58:1. The posterior glandular portion (Eg) is $0.06(0.05-0.08)$, from which a free glandular appendage (Ap) arises, $0.15(0.14-0.18)$ long.

The nerve ring $(\mathrm{An})$ is located $0.31(0.21-0.48)$ from the anterior end (fig. 1). The genital system is didelphic; the anterior ovary is reduced and the posterior ovary $(\mathrm{Ov})$ is 0.74 from the posterior end of the body, lacking vulva. The intestine (In) runs ventrally to the ovary; the tail is 0.64 (0.56-0.70) long (fig. 2).

Larvae, filiform, found in the interior of the uterus (Ut) of the adults, measure $0.11(0.074$ 0.15 ). It was not possible to differentiate their internal anatomy under the optical microscope (fig. 3).

Material studied: 150 specimens. The measurements given correspond to 25 females.

Location in the host: Swim bladder.

Host: Merluccius hubbsi Marini, 1933.

Locality: Southwestern Atlantic Ocean $\left(34^{\circ}\right.$ to $\left.48^{\circ} \mathrm{S}\right)$.

Type material: Deposited in the collection of the Instituto Nacional de Investigación y Desarrollo Pesquero, holotype No. $0054 \mathrm{H}$; paratype No. $0065 \mathrm{H}$. 


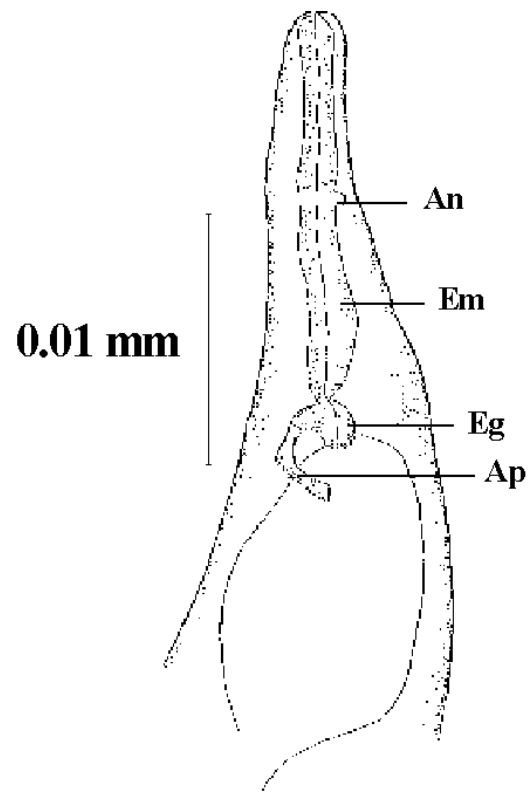

Figura 1

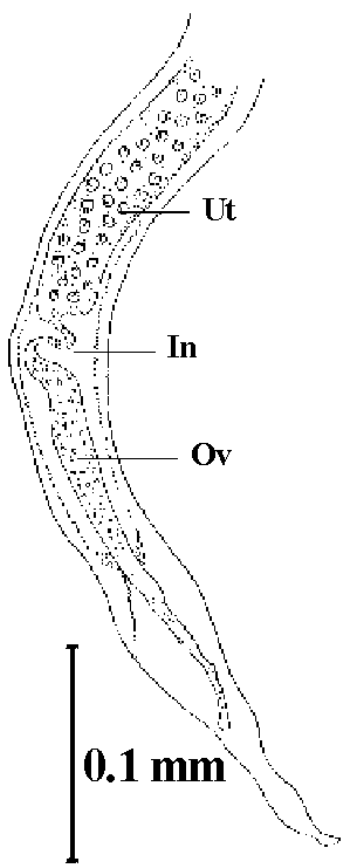

Figura 2

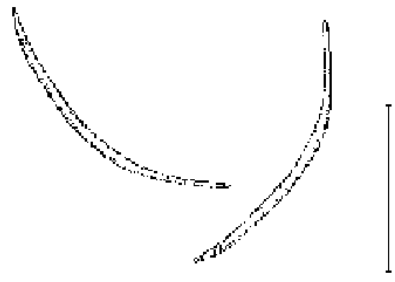

\section{$0.05 \mathrm{~mm}$}

\section{Figura 3}

Figura 1: Ichthyofilaria argentinensis. Extremidad anterior, vista lateral. An: anillo nervioso; Em: esófago muscular; Eg: esófago glandular; Ap: apéndice glandular. Figura 2: Extremidad posterior, vista lateral. Ut: útero; In: intestino; Ov: ovario posterior. Figura 3: Larvas de Ichthyofilaria argentinensis.

Figure 1: Ichthyofilaria argentinensis. Anterior end, lateral view. An: nerve ring; Em: muscular oesophagus; Eg: glandular oesophagus; Ap: glandular appendage. Figure 2: Posterior end, lateral view. Ut: uterus; In: intestine; Ov: posterior ovary. Figure 3: Ichthyofilaria argentinensis larvae. 


\section{DISCUSIÓN}

Hasta el presente, el género Ichthyofilaria comprende las siguientes especies: I. dasycotti, Yamaguti 1935, parásita de Dasycottus setiger (Cottidae), de Toyama, Japón; I. japonica, Moravec et al., 1985, parásita de Sebastes schlegeli (Scorpaenidae) de Hokkaido, Japón; I. canadensis, Appy et al., 1985, parásita de Lycodes lavalaei y L. vahlii (Zoarcidae), de Canadá.

La especie aquí propuesta, I. argentinensis, parásita de M. hubbsi del Océano Atlántico Sudoccidental, se diferencia de I. dasycotti por su menor talla y por la relación entre la longitud del cuerpo y la longitud del esófago muscular, que para $I$. dasycotti es de 100:1 vs 58:1 para $I$. argentinensis. Por otra parte, se diferencia de $I$. japonica porque carece de proyecciones cefálicas y de $I$. canadensis porque el apéndice glandular es libre y no está incluido dentro del intestino.

Ésta es la primera vez que un nematodo del género Ichthyofilaria ha sido hallado en la vejiga natatoria de un miembro de la familia Merluccidae. En efecto, las restantes especies del género son parásitas de la cavidad abdominal, corazón y vesícula de peces pertenecientes a las familias Scorpaenidae, Cottidae y Zoarcidae.

La ausencia de machos en todas las especies descritas hasta el momento resulta sumamente extraña. Appy et al. (1985) interpretan esta ausencia como posible consecuencia de una degeneración tras de la fertilización de las hembras.

Es interesante destacar que Køie (1993) ubicó taxonómicamente en el género Ichthyofilaria a la especie descrita por Wülker (1930) con el nombre de Philometra bergensis, parásita de Molva dipterigia del Atlántico Norte; la mencionada especie fue nombrada entonces $I$. bergensis (Wülker, 1930). En el presente trabajo no se considera al nematodo descrito por Køie (1993) perteneciente al género Ichthyofilaria.

\section{DISCUSSION}

To date, the genus Ichthyofilaria comprises the following species: I. dasycotti, Yamaguti 1935, parasite of Dasycottus setiger (Cottidae), from Toyama, Japan; I. japonica, Moravec et al., 1985, parasite of Sebastes schlegeli (Scorpaenidae) from Hokkaido, Japan; I. canadensis, Appy et al., 1985, parasite of Lycodes lavalaei and L. vahlii (Zoarcidae), from Canada.

The species presented herein, I. argentinensis, parasite of $M$. hubbsi from the Southwest Atlantic Ocean, can be distinguished from I. dasycotti by its smaller size and by the relation between the length of the body and the length of the muscular oesophagus, which is 100:1 for I. dasycotti and 58:1 for I. argentinensis. Likewise, it differs from I. japonica because it lacks cephalic projections and from $I$. canadensis because the glandular appendage is free and not included within the intestine.

This is the first time that a nematode of the genus Ichthyofilaria has been found in the swim bladder of a member of the family Merluccidae. The other species of the genus are parasites of the abdominal cavity, heart and vesicle of fishes belonging to the families Scorpaenidae, Cottidae and Zoarcidae.

The absence of males in all the species described to date is very odd. Appy et al. (1985) interpret this absence as a possible consequence of a degeneration following the fertilization of the females.

It is interesting to note that Køie (1993) taxonomically included in the genus Ichthyofilaria the species described by Wülker (1930) with the name of Philometra bergensis, parasite of Molva dipterigia from the North Atlantic; this species was then named I. bergensis (Wülker, 1930). The nematode described by Køie (1993) of the genus Ichthyofilaria was not considered in this study.

English translation by Christine Harris. 
Ciencias Marinas, Vol. 25, No. 3, 1999

\section{REFERENCIAS}

Appy, R.G., Anderson, R.C. and Khan, R.A. (1985). Ichthyofilaria canadensis n.sp. (Nematoda: Dracunculoidea) from eelpouts (Lycodes spp.). Can. J. Zool., 63: 1590-1592.

Køie, M. (1993). Nematode parasites in Teleost from 0 to $1540 \mathrm{~m}$ depth off the Faroe Islands (the North Atlantic). Ophelia, 38(3): 217-243.
Szidat, L. (1955). La fauna de parásitos de Merluccius hubbsi como carácter auxiliar para la solución de problemas sistemáticos y zoogeográficos del género Merluccius. Comun. Inst. Nac. Invest. Cienc. Natur., Mus. Argentino Cienc. Natur. Bernardino Rivadavia, 3(1): 1-54.

Wülker, G. (1930). Uber Nematoden aus Nordseetieren II. Zool. Anz., 88: 1-16. 